\title{
First report of powdery mildew caused by Podosphaera sp. on Cynanchum auriculatum
}

\author{
Narayan Chandra Paul ${ }^{1,2} \cdot$ Sang-Keun $\mathrm{Oh}^{3} \cdot$ Young-Guk Kim ${ }^{1} \cdot$ Seon-Woo $\mathrm{Cha}^{1}$ • \\ Tae-Jin An ${ }^{1}$
}

Received: 15 February 2016 / Accepted: 11 October 2016/Published online: 15 October 2016

(C) Australasian Plant Pathology Society Inc. 2016

\begin{abstract}
Powdery mildew symptoms were observed on the upper surface of leaves of Cynanchum auriculatum in Eumseong, Korea in October 2015. Microscopic observations and molecular characteristics determined this fungus as Podosphaera sp., which is reported for the first time on Cynanchum auriculatum.
\end{abstract}

Keywords Cynanchum auriculatum · Podosphaera sp. · ITS $\cdot$ Morphology $\cdot$ Powdery mildew

Cynanchum auriculatum is a climbing vine, which is a species of swallow-worts under the family Apocynaceae. The plant is native to Asian temperate and tropical regions and is found in China, Korea, Bhutan, Nepal, northern parts of Pakistan and India. The habitat of this plant is mountainous shrubland terrain. The plant leaf extracts have been used traditionally as medicine.

Typical symptoms of powdery mildew were observed on the leaves of Cynanchum auriculatum in National Institute of Horticultural and Herbal Science (NIHHS) glasshouse, Eumseong, Korea during October-November, 2015. The

Tae-Jin An

atj0083@korea.kr

1 Department of Herbal Crop Research, National Institute of Horticultural and Herbal Science (NIHHS), Eumseong, Chungbuk 27709, Republic of Korea

2 Bioenergy Crop Research Institute, National Institute of Crop Science, Rural Development Administration, Muan 58545, Republic of Korea

3 Department of Applied Biology, College of Agriculture \& Life Sciences, Chungnam National University, Daejeon 34134, Republic of Korea upper surface of the leaves of Cynanchum auriculatum were covered with superficial, white and dense mycelia with conidiophores and conidia (Fig. 1). Around $20 \%$ of leaves exhibited powdery mildew symptoms. Diseased plant leaf samples were collected and preserved in 'Plant Disease and Pest Lab.', NIHHS, Eumseong, Korea (ID: HCRD15501).

The disease occurrence was observed only on the Cynanchum auriculatum plant leaves. Cynanchum wilfordii, another plant species in the Apocynaceae family, was grown in the same glasshouse, but did not display any powdery mildew symptoms. The disease might be host specific.

Microscopic observations of the fungal hyphae revealed upright chains of ellipsoidal to cylindrical conidia (2 to 6 conidia/chain) and the length and width of conidia were 35.3 $(28.2-42.0) \times 20.8(16.2-25.0) \mu \mathrm{m}(n=26)$ with a length-towidth ratio of 1.4 to 2.2 . Conidiophores were mostly erect to curved, 198.5 to $262.6 \mu \mathrm{m}$ long. The foot cells in conidiophores were cylindrical, 50.0 to $80.5 \mu \mathrm{m}$ long and constricted at the base (Fig. 2). Indistinct appresorium were observed and no chamosthecia were found. Based on the morphological characteristics, the fungus was identified as Podosphaera sp. (Braun et al. 2002; Chen et al. 2015). Morphologically, Podosphaera sp. from this study was similar to P. xanthii, $P$. fusca and $P$. fuliginea. Conidial shapes were more similar to $P$. xanthii than $P$. fusca and $P$. fuliginea (Table 1). But Cho et al. (2013) described $P$. xanthii producing a higher number of conidia (up to 12) on a single chain, whereas the present fungus produced a maximum of 6 conidia.

To confirm the identity Podosphaera sp. obtained in the present study, genomic DNA was extracted using the Solg ${ }^{\text {TM }}$ Genomic DNA prep. Kit (Solgent Co. Ltd., Daejeon, South Korea) and the internal transcribed spacer (ITS) region of rDNA was amplified using the primer sets ITS5 and ITS4 (White et al. 1990). Amplification reactions were performed in a total volume of $50 \mu \mathrm{L}$, containing $0.5 \mathrm{pmol}$ of each 
Fig. 1 Symptoms of powdery mildew on leaves of Cynanchum auriculatum
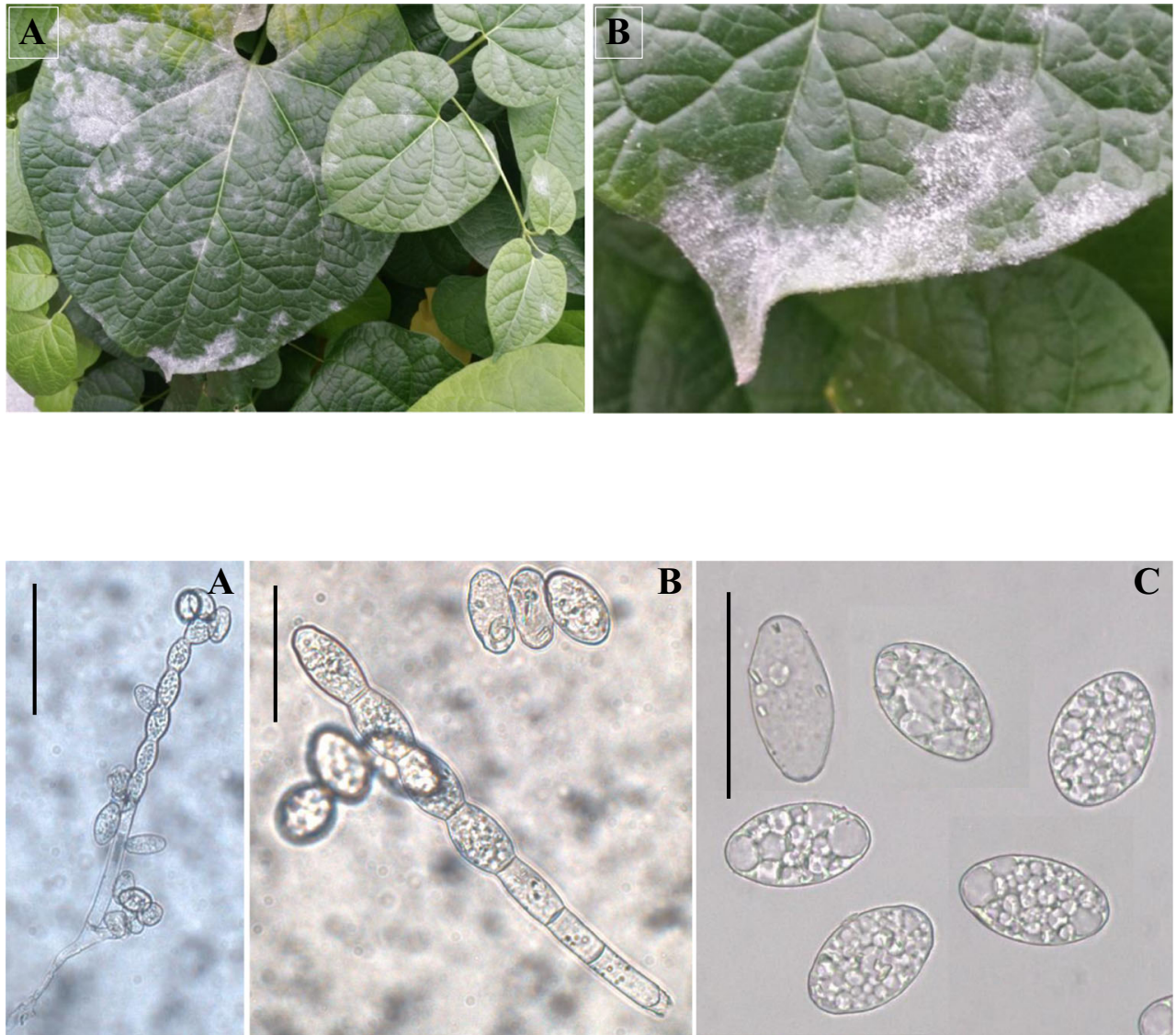

Fig. 2 Conidiophores and conidia of Podosphaera sp. from Cynanchum auriculatum leaves. $\mathbf{a}-\mathbf{b}$; conidiophores with chain of conidia c; Conidia. Scale bars (a; $100 \mu \mathrm{m}$ and $\mathbf{b}-\mathbf{c} ; 50 \mu \mathrm{m}$ ) primer, dNTPs at $0.2 \mathrm{mM}, 10 \mathrm{mM}$ Tris- $\mathrm{HCl}, 50 \mathrm{mM} \mathrm{KCl}$, $1.5 \mathrm{mM} \mathrm{MgCl}_{2}, 2.5 \mathrm{U}$ of Taq polymerase, and $15 \mathrm{ng}$ of template DNA. PCR was carried out in iCycler® Flexibility (BIORAD, USA) under the following conditions: initial denaturation $5 \mathrm{~min}$ at $94{ }^{\circ} \mathrm{C}$ followed by 30 cycles of denaturation $1 \mathrm{~min}\left(94^{\circ} \mathrm{C}\right)$, annealing $1 \mathrm{~min}\left(55^{\circ} \mathrm{C}\right)$, extension $1.30 \mathrm{~min}$ $\left(72{ }^{\circ} \mathrm{C}\right.$ ) and final extension $10 \mathrm{~min}$ at $72{ }^{\circ} \mathrm{C}$ (Paul et al. 2012). PCR products were purified using a Wizard® PCR prep kit (Promega Corporation, Madison, WI, USA) and sequenced using a commercial sequencing service provider (Macrogen, Seoul, South Korea). Sequencing was done using forward ITS5 primer. The resultant sequence was deposited in

Table 1 Morphological comparison of the present fungus (Podosphaera sp. HCRD15501) with related species

\begin{tabular}{|c|c|c|c|c|c|}
\hline Species & Conidial size $(\mu \mathrm{m})$ & $\begin{array}{l}\text { No. of conidia } \\
\text { in chains }\end{array}$ & $\begin{array}{l}\text { Length-width } \\
\text { ratio }\end{array}$ & $\begin{array}{l}\text { Foot-cells }(\mu \mathrm{m}) \\
\text { with shorter cells }\end{array}$ & Reference \\
\hline $\begin{array}{l}\text { Podosphaera sp. } \\
\text { (HCRD15501) }\end{array}$ & $\begin{array}{l}\text { Ellipsoidal to ovate, sometime } \\
\quad \text { cylindrical } 28.2-42.0 \times 16.2-25.0\end{array}$ & $2-6$ & $1.4-2.2$ & $50.0-80.5 \times 10.1-13.0,2-3$ & Present study \\
\hline P. fusca & ellipsoid to ovoid $17-33 \times 13-18$ & $4-6$ & $1.4-2.1$ & $-\overline{1-3}$ & Xu et al. 2015 \\
\hline P. fuliginea & ellipsoid-ovoid to doliform $24-35 \times 15-19$ & $-{ }^{\mathrm{a}}$ & $1.2-2.0$ & $\begin{array}{l}45-95 \times 9.5-12 \\
2-3\end{array}$ & Braun 1987 \\
\hline P. xanthii & ellipsoid to ovate $32-48 \times 17.5-25$ & $2-12$ & $1.4-2.3$ & $\begin{array}{l}50 \times 95 \\
2-3\end{array}$ & Cho et al. 2013 \\
\hline P. balsaminae & $27-45 \times 15-21$ & - & 1.87 & $35.5-97.5 \times 11-15$ & Wolcan 2004 \\
\hline
\end{tabular}

${ }^{\text {a }}$ Not described 
Fig. 3 One of the parsimonious trees inferred from the sequence of ITS region. Numbers above the branches are bootstrap values in 1000 bootstrap replicates. The scale bar indicates the number of nucleotide substitutions.

GenBank accession numbers are represented in the parentheses

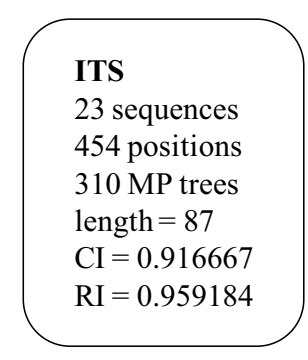

Podosphaera balsaminae (FJ625796)

Podosphaera fuliginea (JN860054)

HCRD15501

Podosphaera fusca (KP329589)

Podosphaera xanthii (D84377)

Podosphaera xanthii (AB774158)

65 Podosphaera xanthii (D84386)

Podosphaera fusca (KJ698669)

Podosphaera fuliginea(JN627138)

Podosphaera fuliginea (JN627140)

71 Podosphaera fuliginea(EU294368)

- Podosphaera fusca (EF137841)

Podosphaera xanthii (KM260741)

87

Podosphaera xanthii (AB040324)

Podosphaera hibiscicola (AB040308)

Podosphaera euphorbiae-hirtae (AB040306)

- Podosphaera balsaminae (AB462806)

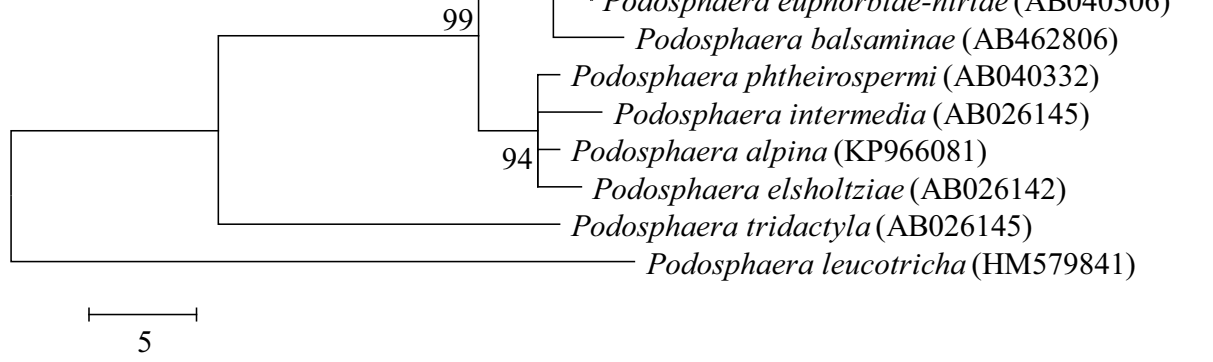

GenBank, (accession number KU711923) and compared with the sequences of related species available in the GenBank database, by using BLAST search. The sequence generated from the materials used in the present study and the sequence retrieved from GenBank was initially aligned using the CLUSTAL X program (Thompson et al. 1997). Phylogenetic relationships were estimated by a maximum parsimony analysis using the MEGA 5 program. Bootstrap analysis using 1000 replications was performed to assess the relative stability of the branches (Tamura et al. 2011). The tree was rooted with the sequence of $P$. leucotricha (HM579841).

BLAST search analysis showed $100 \%$ sequence similarity with Podosphaera xanthii (KM260741), P. fusca (KP329589), P. fuliginea (JN627140) and P. balsaminae (FJ625796). The maximum parsimony analysis revealed that the fungus obtained in this study clustered together with the species (Podosphaera xanthii, P. fusca, P. fuliginea and P. balsaminae) mentioned earlier (Fig. 3.). Based on the results, it is clear that the powdery mildew pathogen on Cynanchum auriculatum belongs to the genus Podosphaera. These four Podosphaera species, belong to the fusca-xanthii group (Braun and Cook 2012) and are different species. However, recently, many researchers have merged Podosphaera species together as $P$. xanthii because of their molecular single cluster formation and morphological similarities (Eg. P. balsaminae, P. fusca to P. xanthii) (Brielmaier-
Liebetanz et al. 2015). To the best of our knowledge, this is the first record of the powdery mildew Podosphaera sp. on Cynanchum auriculatum.

Acknowledgments This study was supported by the Basic Research Program (Project No. PJ00985604) funded by Rural Development Administration, Republic of Korea.

\section{References}

Braun U (1987) A monograph of the Erysiphales (powdery mildews). Beihefte zur Nova Hedwigia 89:134

Braun U, Cook RTA (2012) Taxonomic manual of the Erysiphales (powdery mildews). CBS-KNAW Fungal Biodiversity Centre, the Netherlands

Braun U, Cook RTA, Inman AJ, Shin HD (2002) The taxonomy of powdery mildew fungi. In: B'elanger, RR, Bushnell, WR, Dik, AJ, Carver, TLW (ed) The powdery mildews: a comprehensive treatise, 3rd edn. St. Paul: APS Press, USA, pp. 13-55

Brielmaier-Liebetanz U, Field AE, Warfield CY, Braun U (2015) Powdery mildew (Erysiphaceae) on Calibrachoa hybrids in Germany, Nicaragua and the USA. Plant Pathol Quar 5:1-5

Chen YM, Huang TC, Liu HL, Chao CH (2015) First report of the powdery mildew Podosphaera xanthii on Gynura bicolor. Australas Plant Dis Notes 10:27

Cho SE, Shin CH, Shin HD (2013) First confirmed report of powdery mildew caused by Podosphaera xanthii on Farfugium japonicum in Korea. Dis Notes 97:691 
Paul NC, Deng JX, Sang HK, Choi YP, Yu SH (2012) Distribution and antifungal activity of endophytic fungi in different growth stages of chili pepper (Capsicum annuum L.) in Korea. Plant Pathol J 28:10-19

Tamura K, Peterson D, Peterson N, Stecher G, Nei M, Kumar S (2011) MEGA5: molecular evolutionary genetics analysis using maximum likelihood, evolutionary distance, and maximum parsimony methods. Mol Biol Evol 28:2731-2739

Thompson JD, Gibson TJ, Plewniak F, Jeanmougin F, Higgins DG (1997) ClustalX: windows interface: flexible strategies for multiple sequence alignment aided by quality analysis tools. Nucleic Acids Res 25:487-488
White TJ, Bruns TD, Lee S, Taylor JW (1990) Amplification and direct sequencing of fungal ribosomal RNA genes for phylogenetics. In: Innis MA, Gelfand DH, Sninsky JJ, White TJ (eds) PCR protocols: a guide to methods and applications. Academic Press, Inc., San Diego, pp. 315-322

Wolcan SM (2004) Podosphaera balsaminae on Impatiens balsamina and Impatiens $\times$ hawkeri. Australas Plant Pathol 33:133-134

$\mathrm{Xu}$ XC, Pei DL, Zhao ML, Li CW (2015) First report of powdery mildew caused by Podosphaera fusca on Potentila supina in China. Plant Dis 99:1862 